\title{
DZIEWIĘTNASTOWIECZNY KIJÓW OCZAMI POLSKICH MIESZKAŃCÓW I PODRÓŻNIKÓW: KWESTIE POETYKI MIASTA W LITERATURZE PAMIĘTNIKARSKIEJ
}

\author{
Mariya Bracka \\ Narodowy Uniwersytet imienia Tarasa Szewczenki w Kijowie \\ Kijów, Ukraina \\ ORCID: 0000-0002-0883-9973
}

\section{$19^{\text {TH }}$-CENTURY KIEV THROUGH THE EYES OF POLISH RESIDENTS AND TRAVELERS: ISSUES OF CITY POETICS IN MEMOIRE}

\begin{abstract}
The article analyzes literary visions of the urban space of Kiev in the 19th century, created by marginalized writers of the Polish-Ukrainian borderland, including Aleksander Groza, Antoni Marcinkowski and Michał Czajkowski. The antinomian character of the urban space was emphasized, its sound and color perspective as well as its vertical and horizontal structure were outlined.
\end{abstract}

Key words: urban space, Kyiv, antinomy, vertical - horizontal, sacred - profane

Przestrzeń Kijowa oraz miast i miasteczek Prawobrzeżnej Ukrainy XIX wieku - Berdyczowa, Żytomierza, Kamieńca Podolskiego, Krzemieńca, Owrucza $\mathrm{i}$ in. - wielokrotnie znalazła swoje odbicie w twórczości polskich pisarzy, pamiętnikarzy, publicystów tego okresu'1. W związku z unikalną sytuacją społeczną i kulturową, która wytworzyła się na tych ziemiach wskutek wieloletniego funkcjonowania w organizmie państwowym Rzeczypospolitej, a później - Imperium Rosyjskiego, a jednocześnie mimo ciągłego istnienia na pograniczu kilku kultur narodowych (ukraińskiej, rosyjskiej, polskiej, żydowskiej $\mathrm{i}$ in.), przestrzeń Wołynia, Podola, Ukrainy Naddnieprzańskiej dla wielu pokoleń inteligencji polskiej była przestrzenią „swoją”, ojczystą, zwykłą, traktowaną w kategoriach ziemi rodzinnej. Odosobniony na tle różnorakich paradygmatów urbanistycznych, zapisanych w spuściźnie autorów polskich, pozostaje Kijów jako najbardziej oddalony na wschód punkt kresowy, miasto, usytuowane na granicy z „innym” - rosyjskim - światem, a jednocześnie centrum, ośrodek życia politycznego, kulturowego i duchowego guberni, eg-

1 Obszernie na ten temat pisze między innymi: В. Єршов, Польська мемуаристична література Правобережної Украӥни доби романтизму, Житомир 2010, с. 217-256. 
zotyczne i pociągające miejsce, kolebka tradycji prawosławnej, „wszechsłowiańska stolica ducha słowiańskiego"². Ciekawe, że jak do tej pory Kijów w perspektywie kulturowej i literackiej ${ }^{3}$ był badany dość sporadycznie w porównaniu choćby do kulturowych i literackich obrazów Lwowa, Drohobycza, Krzemieńca ${ }^{4}$, najbardziej dokładnie chyba w odniesieniu do twórczości Michaiła Bułhakowa ${ }^{5}$ czy Jarosława Iwaszkiewicza ${ }^{6}$. Natomiast poza uwagą badaczy pozostaje obraz Kijowa nakreślony we wspomnieniach wielu polskich twórców, zamieszkujących Kijów, przyjeżdżających do niego w interesach, studiujących na Uniwersytecie św. Włodzimierza, zaglądających do niego w celach turystycznych. Dlatego też obiektem badań w niniejszym artykule są wspomnienia niegdyś znanych i poczytnych, a obecnie marginalizowanych pisarzy: Aleksandra Grozy, Antoniego Marcinkowskiego, Michała Czajkowskiego, w których uwidaczniają się właściwości przestrzeni urbanistycznej Kijowa XIX wieku. Celem tych rozważań jest uchwycenie specyfiki obrazu miasta, jaki rysuje się w piśmiennictwie przedstawicieli polskiej społeczności, czyli etnicznie i kulturowo różnej od dominującej w otoczeniu.

Yi-Fu Tuan wyodrębnił symbole i znaki utożsamiania się z pewną przestrzenią, znamienne także dla egzystencjalnej sytuacji społeczności polskiej na terenach ukraińskich: „Ziemia rodzinna ma swoje punkty charakterystyczne, którymi mogą być elementy bardzo widoczne i powszechnie zrozumiałe, takie jak pomniki i świątynie, jak pole bitwy czy cmentarz. Te widoczne znaki zwiększają w ludziach poczucie tożsamości, budzą świadomość i lojalność wobec miejsca. Jednakże silne przywiązanie do ziemi rodzinnej może zrodzić się niezależnie od wszelkich uznanych pojęć świętości: może powstać bez udziału pamięci bohaterskich bitew, wygranych czy przegranych, i bez poczucia lęku czy wyższości wobec innych ludzi. Przywiązanie głębokie, choć nieświadome, może pojawić się łatwo wraz z poczuciem bezpieczeństwa i za-

\footnotetext{
2 M. Czajkowski, Pamiętniki Sadyka Paszy Michała Czajkowskiego. Tłum. na polskie A.P., Lwów 1898, s. 80.

Wspomnieć tu należy tom: Киї і слов'янські літератури. Збірник, uporz. Д. Айдачич, Київ 2013.

4 Wśród innych publikacji należy wymienić: Львів: місто - суспільство - культура. Збірник наукових праць, т. 10, ч. 1: Львів / Lwów / Lemberg як міські простори: уявлення, досвіди, практики, red. О. Аркуша, О. Вінниченко, М. Мудрий, Львів 2016; Львів - місто натхнення. Література, red. О. Муха, Львів 2017; Drohobycz wielokulturowy. Багатокультурний Дрогобич, red. М. Домбровський і В. Меньок, Варшава 2005; Волинські Афіни 1805-1833. Збірник наукових праць, red. С. Маковський і В. Собчук, Тернопіль 2006.

5 Zob.: M. Pietrowski, Mistrz i miasto. Kijowskie konteksty Michaiła Buthakowa, thum. I. Kuźmina, A. Jezierska, Poznań 2004, a także słowo wstępne do tej publikacji autorstwa Bogusława Bakuły.

6 Zob.: L. Suchomłynow, Kijów Jarostawa Iwaszkiewicza: miasto rodzące literaturę, „Lamus: pismo kulturalno-artystyczne" 2011, nr 1/7, s. 68-77.
} 
spokajania biologicznych potrzeb, z pamięcią zapachów i dźwięków, społecznych działań i przyjemności domowych, które gromadzą się z czasem"”.

Rzecz jasna, Polacy na terenach Ukrainy mieli i mają sporo narodowych i osobistych punktów odniesienia, znaków, miejsc umacniających poczucie tożsamości i wierności wobec ziemi, która ich wydała na świat. Wszystkie pozostają cechami charakterystycznymi dla swoistej pogranicznej czasoprzestrzeni, co znalazło odbicie we wspomnieniach i utworach fabularnych, artykułach i notatkach z podróży. Jednocześnie znajdujemy u wspomnianych pisarzy polskich potwierdzenie kolejnej tezy Tuana: ziemia ukraińska, między innymi Kijów, to miejsce, gdzie Polacy mieli poczucie swojskości, gdzie czuli się u siebie, gdzie doznawali poczucia bezpieczeństwa, a przez to pewności siebie. Przestrzeń miasta i okolic dostarczała wrażeń, które ich kształtowały poprzez weduty miejskie i krajobrazy okolic miasta, wszelkie bodźce wzrokowe, oryginalne zapachy, bliskie sercu dźwięki, kolory składające się na pamięć o sobie, swoim rodowodzie, budujące lokalną tożsamość.

Życie w Kijowie, utożsamianie się z miastem jako z miejscem urodzenia, znanym od najwcześniejszych lat życia, wchłanianie jego atmosfery, a nawet postrzeganie jako nudnego miasta, rodzi poczucie przywiązania do miejsca wrośnięcia w nie przez sam fakt stałego pobytu i doświadczania niejako od środka. Świadczą o tym na przykład słowa Antoniego Marcinkowskiego, który pisał:

Przyznam ci się, iż lubię Kijów pomimo całej atmosfery nudy, jaką się w nim oddycha; lubię go może dlatego, iż urodziłem się w jego okolicach, iż w dzieciństwie jeszcze wraziły mi się w pamięć jego złocone kopuły i szpice, iż przez trzy lata uczyłem się w drugim jego gimnazjum i słuchałem kursu literatury i filozofii w Uniwersytecie S-go Włodzimierza. Wszystko to razem sprawiło może to, iż jestem w Kijowie jak u siebie, iż nawet ziewnięcie w Kijowie przybiera u mnie charakter sentymentalnego westchnienia... ${ }^{8}$.

Rozpoczynając analizę tematyki urbanistycznej w tekstach pamiętnikarskich, należy podkreślić osobliwości budowania chronotopu w piśmiennictwie tego rodzaju. Jak zaznaczał Wołodymyr Jerszow, badając memuarystykę autorów zamieszkujących Prawobrzeżną Ukrainę, pamiętniki i wspomnienia prezentują „szeroką retrospektywę wydarzeń, związanych z określoną czasoprzestrzenią, długością w pewien wyodrębniony okres życia", a z kolei „przestrzeń urbanistyczna $\mathrm{W}$ prawobrzeżnych tekstach polskojęzycznych

\footnotetext{
7 Y.-F. Tuan, Przestrzeń i miejsce, thum. z ang. Agnieszka Morawińska, Warszawa 1987, s. 201.

8 A. Nowosielski [A. Marcinkowski], Stepy, morze i góry. Szkice i wspomnienia z podróży, Kijów 1854, t. 1, s. 8.

9 В. Сршов, Польська мемуаристична література Правобережної України доби романтизму, ор.cit, s. 83.
} 
w ogóle jest przedstawiona fragmentarycznie"10. Pozostawiając poza obserwacją kwestię opozycji przestrzeni miejskiej i rustykalnej, warto podjąć próbę ułożenia z okruchów wspomnień mozaiki miasta połowy XIX wieku.

Jak wspomniano, opis przestrzeni miasta jest w uwzględnionych tekstach naznaczony wybiórczym traktowaniem opisywanych obiektów, subiektywną oceną ukazywanych realiów, podawane informacje są niepełne, jednostronnie przedstawiane, a to, co historycznie prawdopodobne, łączy się z fikcją. Pamiętnikarze wybierają i opisują tylko te elementy przestrzeni miejskiej (weduta, panorama dźwiękowa, dynamika miejskiego życia), które najsilniej wryły się w jego pamięć, albo tylko swoje wrażenia odniesione w zetknięciu z tymi realiami. Odnotowuje najważniejsze jego zdaniem elementy obserwowanego świata, mające jego zdaniem historyczne, kulturowe albo i kultowe znaczenie. Tak specyficznie ukierunkowana uwaga obejmująca fragmenty przestrzeni urbanistycznej ,przekonująco świadczy o istnieniu genetycznie różnych etnicznych modeli kultur, uwarunkowanych przez różnego pochodzenia mity społeczne, tradycje i właśnie historię"11.

Na podstawie wspomnień pamiętnikarzy można dojść wniosku, że w połowie XIX wieku Kijów, choć jeszcze utrzymywał swoje znaczenie jako centrum życia społecznego i kulturowego, już tracił ważną rolę jako centrum handlowe. W związku z rozszerzeniem stref handlu dokonała się decentralizacja - kijowskie jarmarki kontraktowe ${ }^{12}$ utraciły swoje pozycje targów ekskluzywnych, gdzie można było nabyć ekskluzywne towary, niedostępne w innych zakątkach Prawobrzeżnej Ukrainy. Jak pisał Aleksander Groza, już w połowie XIX wieku wskutek oswojenia się z ówczesnymi dobrami cywilizacyjnymi, dostępnymi nie tylko w wielkich miastach, Kijów jako centrum handlu utracił swój wyjątkowy charakter ${ }^{13}$. Jarmarki współtworzyły szczególną atmosferę miasta. Dla szlachty polskiej Prawobrzeżnej Ukrainy udział w nich oznaczał uczestnictwo w pewnego rodzaju świętach, w wypoczynku i zabawie. Obok załatwiania ważnych spraw handlowych i majątkowych przyjezdni odwiedzali krewnych, znajomych, przyjaciół, bawili się, zażywali miejskiej atmosfery. Słowo „kontraktować” oznaczało bowiem nie tylko „podpisywać kontrakt, umowę”, ale przede wszystkim „brać udział w jarmarku” i stało się synonimem „próżnowania”: „[...] Przyjechałem do Kijowa kontraktować, nigdzie bowiem nie próżnuje się tak kompletnie jak w Kijowie podczas kontraktów [...]"14. Teren miasta Kijowa to przestrzeń spotkań, wspomnień; tu spotykają się rodziny, starzy znajomi i przyjaciele, prowadzi się rozmowy

Ibidem, s. 227.

Ibidem.

Patrz szerzej: H. Ułaszyn, Kontrakty kijowskie, Petersburg 1900.

A. Groza, Mozaika Kontraktowa. Pamiętnik z roku 1851, Wilno 1857, s. 1-2.

A. Nowosielski [A. Marcinkowski], Stepy, morze i góry. Szkice i wspomnienia z podróży, op. cit., t. 1, s. 7. 
o przeszłości i teraźniejszości oraz buduje się plany na przyszłość. Dominuje wesołość, zabawy, nastrój karnawałowy: „Kijów nasz był nadzwyczaj wesół w tym roku, w lutym, zabawy były liczne; wieczory i bale tu i ówdzie; tańczono do upadłego; stroje kobiece były niesłychanej wartości [...]"15. Jednocześnie miasto rozwija się, rozszerza swoje granice - Kijów jawi się jako dynamiczne centrum miejskie o szybkim tempie i rytmie życia, otwarte także na przyszły wzrost.

Główną zasadą konstrukcji i jednocześnie oceny przestrzeni urbanistycznej w pamiętnikach jest kontrast, którego rola polega na odsłanianiu i uwypuklaniu antynomii ${ }^{16}$. Podział na świeckie i sakralne, ukazywanie poziomej i pionowej organizacji przestrzeni miasta, lądu oraz wody, hałasu wobec ciszy, dźwięków dzwonów w opozycji do ludzkiego zgiełku, ruchu względem bezruchu - to tylko niektóre opozycyjne pary, wyodrębnione w artystycznej wizji urbanistycznej Kijowa XIX wieku. Jak już można było zauważyć w przytoczonych cytatach, miasto generalnie odznaczało się kontrastowością. Łączyła się w nim atmosfera jarmarku, czyli ziemskiego, ludzkiego święta, z sakralnością świątyń, ich podniosłego sanctum.

Polscy pisarze-pamiętnikarze akcentują wielopoziomowość pionowej organizacji przestrzeni kijowskiej:

Słońce szło ku zachodowi; jego promienie odbijały się na kopułach pobliższych cerkwi, na dachach domów, na górach otaczających Padół, a nade wszystko na cerkwi ś. Andrzeja, która jak gromnica postawiona na białym góry ołtarzu płonęła cichym wieczornym światłem. I odzywały się dzwony ku dzwonom, płynąc ku sobie w górnej atmosferze, ledwie słyszane przy ziemi; gdzie była swoja ciągła wrzawa, natłok, hałas - najdziksza harmonia razem grających tysiąca różnobarwnych myśli, uczuć, chęci ${ }^{17}$.

Jak widać, przestrzeń urbanistyczna Kijowa kształtuje się na co najmniej trzech poziomach, które się łączą w trajektorię spojrzenia narratora od dołu do góry: poziom samego narratora, dachy budowli i kopuly cerkwi oraz najwyższy punkt - Cerkiew św. Andrzeja na górze-ołtarzu, unoszącym się nad miastem i niby wieńczącym miejską przestrzeń sakralną i świecką. Odczucia wzrokowe łączą się ze słuchowymi: piękny krajobraz lśniący blaskiem zachodzącego słońca harmonizuje z dźwiękami rozdzielonymi na dwie płaszczyzny: sakralny, „wysoki” poziom świątynnych dzwonów i ,uziemiona” warstwa, w której panuje kakofonia ludzkich głosów i dźwięków.

15 Ibidem, s. 34.

16 A. Martuszewska, Poetyka przestrzeni miasta w powieści klasycznego realizmu, [w:] Miasto-kultura-literatura. Wiek XIX. Materiały sesji naukowej, red. J. Data, Gdańsk 1993, s. 90.

17 A. Groza, Mozaika Kontraktowa. Pamiętnik z roku 1851, op. cit., s. 30. 
Miasto stale rozrasta się w płaszczyźnie pionowej: „[...] Znikają dawne okopy, wyrównywają się odwieczne jary i doły, a na nich powstają domy i całe ulice architektury coraz to poprawniejszej"18. Do góry wyciągają się budynki sakralne, wspomniane przez narratora: Dziesięcinna Cerkiew, Cerkiew św. Andrzeja, zbudowane zresztą na wzgórzach, co już wynosi je ponad poziom miasta ${ }^{19}$. Górę i dół, wzgórze i dolinę łączą drogi, które stają się charakterystycznymi elementami miejskiej przestrzeni Kijowa. Drogi łączące górne i dolne miasto wyznaczają miejski pion:

[...] Kijów w kontrakty jest pełen życia i ruchu, pełen przyjezdnej ludności, snującej się ustawnie pomiędzy Peczerskiem, Kreszczatykiem i Padołem. Począwszy od arystokratycznych karet, koczów i faetonów na leżących resorach, zaprzężonych pięknymi końmi w angielskich szorach, a przechodząc przez rozmaite gradacje sanek aż do żydowskiej chałabudy i berdyczowskich furmanek, transportujących opóźnione towary: wszystko to zalewa drogę, będącą główną komunikacyjną linią pomiędzy górnym a dolnym miastem. Żandarmi na pięknych gniadych koniach, w szafirowych płaszczach i pięknych kaskach, rysują się malowniczo pomiędzy tym olbrzymim, ruszającym się pasem, ściągającym dwa końce miasta ${ }^{20}$.

Droga $\mathrm{w}$ całej swej rozciągłości, z toczącymi się po niej licznymi pojazdami oraz ruchomymi sznurami przechodniów, które, jak się wydaje, jeszcze bardziej ją rozciągają swym powolnym ruchem, łączy jednak poziome płaszczyzny miasta, usytuowane na osi, jaką wyznaczają Peczersk, Chreszczatyk i Podił (Padół).

Zacytowany wyżej fragment otwiera jeszcze jedną perspektywę przestrzeni urbanistycznej, a jej główną, charakterystyczną cechą jest dynamizm. Mamy do czynienia z wzajemnym powiązaniem procesu „dziania się": miasto jako centrum generuje ruch, a jednocześnie ruch ten określa rzeczywistość miejską i jej charakter. W odbiorze Antoniego Marcinkowskiego miasto porusza się wraz z pojazdami i wędrującymi ludźmi. We wspomnieniach Aleksandra Grozy natomiast Kijów jest wprowadzany w ruch przez Podił z jego jarmarkiem kontraktowym, gdzie wśród setek domów przemieszczają się ludzie - miejscowi i przybyli, gdzie nie zamykają się drzwi składów, gdzie wielki thum skupia się wokół domu kontraktowego, a każdy żyje własnym życiem, własnymi problemami, nowościami i sensacjami ${ }^{21}$.

Dźwięki Kijowa powiązane są przede wszystkim z ruchem i hałasem; nakładające się na siebie treści różnojęzycznych wypowiedzi (ukraińskie, ro-

\footnotetext{
18 Ibidem, s. 23-24.

19 Ibidem, s. 25.

20 A. Nowosielski [A. Marcinkowski], Stepy, morze i góry. Szkice i wspomnienia z podróży, op. cit., t. 1 , s. 9.
}

21 A. Groza, Mozaika Kontraktowa. Pamiętnik z roku 1851, op.cit., s. 28-29. 
syjskie, polskie, hebrajskie, francuskie, niemieckie) stwarzają niepowtarzalną miejską przestrzeń dźwiękową. Kakofonia ludzkich głosów podczas jarmarku kontraktowego wraz ze zmienną gęstością ludzkiego thumu i jego kolorów przypomina narratorowi mieniące się $\mathrm{w}$ oczach figury kalejdoskopu ${ }^{22}$. Nie na darmo jednak Kijów wśród romantyków polskich był uważany za miasto święte. Aurę świętości współtworzyły również kompozycje dźwiękowe. Nie tylko dźwięki sygnalizujące sferę profanum, ale też te pochodzące z sakralnej przestrzeni niepokoją duszę pisarza polskiego:

W święto, już przede dniem zaczynają odzywać się olbrzymie dzwony i budzić [...] jedne drugich; powstaje w powietrzu przeciągła głucha wrzawa, której cisza nocna dozwala swobodnie rozlewać się na wszystkie strony. Każde z trzech miast ma tę swoją muzykę, a której przewodniczy jedno olbrzymie brzmienie; i tak dzwony Ławry przewodniczą na Peczersku, Sofijskiego Soboru na starym Kijowie, a Bratskiego monasteru na Padole. W dniu białym, kiedy się ruch wzmoże, jak gdyby ograniczając się swoją miejscowością, te olbrzymy ryczą tylko w około siebie, głos ich [...] przypada do samej ziemi [...]. A jednakże w Kijowie jest kilkadziesiąt cerkwi, dzwonów można liczyć setkami. Jerychońska orkiestra, od niej mury miasta popękać powinny; tymczasem dzwony huczą, mury stoją i odbijają te brzmiące fale; ale nie same mury miasta, więcej one odbijają góry, połykają wąwozy ${ }^{23}$.

W czasie snu i ciszy nocnej dźwięki klasztornych i cerkiewnych dzwonów opanowują całą przestrzeń miejską, całkowicie ją wypełniają swą grą, która wraz z odległością traci swą dźwięczność i przeistacza się w głuchy huk wnikający we wszystkie zakamarki miasta, tworząc nad nim niewidzialną warstwę dźwiękową. Po rozbudzeniu się otaczającego świata warstwa ta, niby mgła, opada na ziemię, a światło dzienne i nowe dźwięki ją tłumią, zagłuszają, ograniczają sferę jej zasięgu. Sfera dźwiękowa jeszcze raz ukazuje pionową organizację miejskiej przestrzeni Kijowa: duża liczba dźwięków miasta jest wchłaniana przez okoliczne wzgórza, ściany miejskie oraz wąwozy, które jako jego charakterystyczne elementy tworzą kijowskie weduty.

Sacrum i profanum współistnieje w Kijowie nie tylko ze względu na zmieszanie świętych i świeckich budowli oraz kompleksów, ale także dzięki splataniu się dźwięków oraz wyróżnianiu kolorów. Złote promienie odbijają się w złotych kopułach cerkwi, a złoty zachód słońca kontrastuje z bielą Cerkwi św. Andrzeja, która wydaje się ogromną świeczką na wysokim ołtarzu miasta. W najwyższej płaszczyźnie Kijowa płyną od dzwonu do dzwonu uświęcone dźwięki, łącząc się w harmonijną muzykę, kontrastującą z , dzikim” dysonansem rozmaitych ziemskich głosów, emanacji ludzkich myśli, uczuć i chęci.

\footnotetext{
22 A. Nowosielski [A. Marcinkowski], Stepy, morze i góry. Szkice i wspomnienia z podróży, op. cit., t. 1, s. 13.
}

23 A. Groza, Mozaika Kontraktowa. Pamiętnik z roku 1851, op.cit., s. 149-150. 
W kolorystycznym krajobrazie Kijowa, ukazanym przez polskich pamiętnikarzy, dominuje złoty kolor kopuł i biały ścian budynków sakralnych. Semantyka koloru złotego i białego uzasadnia opinię o sakralnym charakterze dawnego centrum prawosławnego chrześcijaństwa. Biały kolor - symbol niewinności, czystości i radości, także znak stworzonego przez Pana Boga świata - łączy się w przestrzeni semantycznej z kolorem złotym - barwą słońca, promieni słonecznych, sygnałem świętości, przebywania w centrum, wertykalnego ukierunkowania, powiązania z żywiołem ognia. Natomiast w antynomicznej, ziemskiej przestrzeni pojawiają się i inne kolory, w które miasto jest bogate. Sygnalizują nie tylko miejską architekturę, lecz ujawniają elementy natury - rzeczki, wzgórza, lasy

Zimą srebrzysty połysk Dniepru pokrył się białym matem; wieś Nikolskoje i cegielnie odbijają się na tym tle czarno jakby na litografii; tu czerwienieją łozy, rosnące na przeciwnym wybrzeżu, (...); z lewej, w siniejącej dali czernieją poleskie lasy, ciągnące się daleko, daleko i ginące nareszcie na widnokręgu, oblewając się purpurowym reflektem zachodzącego słońca $(. . .)^{24}$.

Tak więc zimą w przestrzeni Kijowa dominuje biel śniegu i kontrastująca z nią czerń budowli (cegielnia, chaty wiejskie), srebrny blask wody Dniepru i purpurowe w promieniach zimowego słońca wierzby i dalekie lasy.

Właśnie budowle sakralne stają się główną ozdobą miasta. Wysokość dzwonnicy zespołu architektonicznego Lawry Peczarskiej, z której otwiera się niezwykle piękny widok na okolice Kijowa, daje możliwość uzmysłowienia sobie wielowymiarowości i wielożywiołowości Kijowa: jest on usytuowany na dwóch poziomach - górnym i dolnym; harmonijnie zespalają się w nim co najmniej trzy żywioły: ziemi (lasy), wody (Dniepr) i powietrza (góry - wzgórza). Można nawet mówić o obecności w Kijowie żywiołu ognia, bo przecież złote kopuły dziesiątek cerkwi niejako „płoną” w słońcu, tworząc właściwe sobie efekty wizualne:

Rozkosznie wzrok błądzi w tym czarownym kole złożonym z wód, gór, lasów; zatrzymuje się na różnobarwnym dwupiętrowym Kijowie, bo górnym i dolnym, porozdzielanym sadami, jarami i błyszczącymi złocistymi kopułami stu cerkwi; w końcu znużony odpoczywa na siedmio-kopułowej bani Ławry, gorejącej od złota i słońca ${ }^{25}$.

Żywioł wody od czasu do czasu opanowuje urbanistyczną przestrzeń miasta. Nawet w takim niebezpiecznym zjawisku, jak powódź wiosenna, narrator

\footnotetext{
24 A. Nowosielski [A. Marcinkowski], Stepy, morze i góry. Szkice i wspomnienia z podróży, op. cit., t. 1 , s. 9.

25 A. Groza, Mozaika Kontraktowa. Pamiętnik z roku 1851, op.cit., s. 151.
} 
dostrzega piękno Kijowa, a szczególnie porusza go widok rozlanego Dniepru, który ,zalewa dalekie wioski, odbijające się w srebrzystych jego wodach jak zielone bukiety" ${ }^{26}$. Kijów traci swoje granice, rozmyte przez wodę, i miasto rozrasta się aż po horyzont, wciągając w swoją orbitę całą przestrzeń okolicy.

Jak słusznie zaznaczył Henryk Markiewicz, „obecność tworów przestrzennych pozwala czytelnikowi nie tylko lepiej zrozumieć, ale i wyraźniej skonkretyzować zdarzenia. Dla postaci stanowią one teren ich bycia, obiekty ich działania i poznania, jako otoczenie przedmiotowe - służą ich pośredniej charakterystyce, pełnią także wobec nich funkcje impresywne, tj. oddziaływają na ich stany wewnętrzne"27. W prozie pamiętnikarskiej, gdzie narratorem i głównym bohaterem jest jej autor, złożona i zhierarchizowana przestrzeń miejska Kijowa daje możliwość poznania, które obiekty zaprzątają uwagę piszącego, jak postrzega on antynomiczność miejskich przestrzeni. Można odtworzyć odczuwanie przez autora tempa i rytmu miejskiego życia, wydobyć aksjologiczne przekonania.

Przestrzeń miejska Kijowa, odmalowana w obrazach odtwarzających zapamiętane widoki oraz tworzonych na potrzeby powieściowych fabuł, ma swoje charakterystyczne cechy. Po pierwsze, jest to przestrzeń „własnego” miasta, w którym opisujący ją mieszka na co dzień lub do którego przybywa od czasu do czasu; jest to znajoma, bliska, ojczysta przestrzeń, kontrastująca ze światem znajdującym się poza jej granicami miasta, bo przecież w niej zachowały się pozostałości polskiego świata. Po drugie, dawna historia miasta, jego przeszłość z czasów, gdy było centrum duchowości, określa jego współczesność; budynki świątyń i klasztorów, niejako wywyższają miasto, rozbudowując jego wertykalną strukturę (budowle o sakralnym przeznaczeniu, także dźwięki dzwonów). Po trzecie, wyznaczające pion sacrum łączy się z horyzontalną przestrzenią profanum - światem przyziemnym, napełnionym dobrami cywilizacyjnymi - miastem rozrastającym się w płaszczyźnie poziomej, poszerzającym swoje granic (drogi biegnące do nowych dzielnic, kakofonia dźwięków na ludnym jarmarku kontraktowym). Ostatnią, lecz nie mniej ważną cechą jest szczególne usytuowanie miasta, ze względu na które określają je także żywioły warunkujące jego istnienie: ziemia - powietrze woda. Wszystkie wymienione aspekty podsycają energię rytmu miejskiego. W świadomości mieszkańców i gości powstają dzięki temu niepowtarzalne obrazy przestrzeni miejskiej Kijowa XIX wieku.

\footnotetext{
26 A. Nowosielski [A. Marcinkowski], Stepy, morze i góry. Szkice i wspomnienia z podróży, op. cit., t. 1, s. 8.

27 H. Markiewicz, Czas i przestrzeń w utworach narracyjnych, [w:] Idem, Prace wybrane, t. IV: Wymiary dzieła literackiego, Kraków 1996, s. 152.
} 


\section{BIBLIOGRAFIA}

Ajdačič Deân (Red.). 2013. Kï̌v ì slov'âns'ki literaturi. Zbirnik. Kiïv: Tempora [Айдачич Деян (Ред.). 2013. Київ і слов'янські літератури. Збірник. Київ: Темпора].

Arkuša Olena, Vìnničenko Oleksìj, Mudrij Mar'ân (Red.). 2016. L'vìv: misto - suspil'stvo - kul'tura. Zbìrnik naukovih prac'. T. 10. Cz. 1: L'vìv / Lwów / Lemberg âk mis'ki prostori: uâvlennâ, dosvidi, praktiki. L'vìv: L'vìvs'kij nacìonal'nij unìversitet ìm. İvana Franka [Аркуша Олена, Вінниченко Олексій, Мудрий Мар’ян (Ред.). 2016. Львів: місто - суспільство - культура. Збірник наукових праць. Т. 10. Ч. 1: Львiв / Lwów / Lemberg як міські простори: уявлення, досвіди, практики. Львів: Львівський національний університет ім. Івана Франка].

Czajkowski Michał. 1898. Pamiętniki Sadyka Paszy Michała Czajkowskiego. Tłum. na polskie A.P. Lwów: Nakładem Księgarni Gubrynowicz i Schmidta.

Dąbrowski Mieczysław, Meniok Wiera (Red.). 2005. Drohobycz wielokulturowy. Багатокультурний Дрогобич. Warszawa: Elipsa.

Êršov Volodymyr. 2010. Pol's'ka memuaristična literatura Pravoberežnoï Ukraïni dobi romantizmu. Žitomir: Polìssâ. [Єршов Володимир. 2010. Польська мемуаристична література Правобережної України доби романтизму. Житомир: Полісся].

Groza Aleksandr. 1857. Mozaika Kontraktowa. Pamiętnik z roku 1851. Wilno: Nakładem i drukiem J. Zawadzkiego.

Makovs'kij Stanìslav, Sobčuk Volodimir (Red). 2006. Volins'kì Afini 1805-1833. Zbìrnik naukovih prac'. Ternopil': Bogdan [Маковський Станіслав, Собчук Володимир (Ред). 2006. Волинські Афіни 1805-1833. Збірник наукових праць. Тернопіль: Богдан].

Markiewicz Henryk. 1996. Czas i przestrzeń w utworach narracyjnych. W: Idem. Prace wybrane. T. IV. Wymiary dzieła literackiego. Kraków: Universitas: 137-157.

Martuszewska Anna. 1993. Poetyka przestrzeni miasta w powieści klasycznego realizmu. W: Miasto - kultura - literatura. Wiek XIX. Materiały sesji naukowej. Red. Data J. Gdańsk: Wydawnictwo Gdańskie: 79-92.

Muha Ol'ga (Red.). 2017. L'vìv - misto nathnennâ. Literatura. L'vìv: Vidavnictvo Starogo Leva 2017 [Муха Ольга (Ред.). 2017. Львів - місто натхнення. Література. Львів: Видавництво Старого Лева].

Nowosielski Antoni [Marcinkowski Antoni]. 1854. Stepy, morze i góry. Szkice i wspomnienia z podróży. T. 1-2. Kijów: T. Glückberg.

Pietrowski Miron. 2004. Mistrz i miasto. Kijowskie konteksty Michaiła Bułhakowa. Tłum. I. Kuźmina, A. Jezierska. Poznań: Bonami.

Suchomłynow Lech. 2011. Kijów Jarosława Iwaszkiewicza: miasto rodzace literaturę, „Lamus: pismo kulturalno-artystyczne” nr 1/7: 68-77.

Tuan Yi-Fu. 1987. Przestrzeń i miejsce. Tłum. z ang. Agnieszka Morawińska. Warszawa: Państwowy Instytut Wydawniczy.

Ułaszyn Henryk. 1900. Kontrakty kijowskie. Petersburg: Grendyszyński K. 


\section{DZIEWIĘTNASTOWIECZNY KIJÓW OCZAMI POLSKICH MIESZKAŃCÓW I PODRÓŻNIKÓW: KWESTIE POETYKI MIASTA W LITERATURZE PAMIĘTNIKARSKIEJ}

Streszczenie: W artykule przeanalizowano literackie wizje przestrzeni urbanistycznej Kijowa XIX wieku, stworzone przez marginalizowanych pisarzy pogranicza polsko-ukraińskiego, między innymi Aleksandra Grozę, Antoniego Marcinkowskiego i Michała Czajkowskiego. Uwypuklono antynomiczność przestrzeni miejskiej, nakreślono jej perspektywę dźwiękową, kolorystyczną, jak również strukturą pionową i poziomą.

Slowa klucze: przestrzeń urbanistyczna, Kijów, antynomia, pion - poziom, sacrum - profanum.

\section{КИЇВ ХІХ СТОЛІТТЯ ОЧИМА ПОЛЬСЬКИХ ЖИТЕЛІВ ТА МАНДРІВНИКІВ: ПИТАННЯ МІСЬКОЇ ПОЕТИКИ У МЕМУАРИСТИЧНІЙ ЛІТЕРАТУРІ}

Резюме: У статті проаналізовано літературні уявлення про міський простір Києва в XIX столітті, створені маргіналізованими письменниками польсько-українського пограниччя, зокрема Олександром Грозою, Антонієм Марцінковським і Міхалом Чайковським. Підкреслено антиномічний характер міського простору, окреслено його звукову та кольорову перспективу, а також вертикальну та горизонтальну структуру.

Ключові слова: урбаністичний простір, Київ, антиномія, вертикаль - горизонталь, сакральне - профанне. 
